\title{
INNOVATION IN RUSSIAN AGRICULTURE: CURRENT STATE AND PROBLEMS
}

\author{
Galina Smolnikova \\ South Russia Institute of Management, Russia Presidential Academy of National Economics and Public \\ Administration, Rostov-on-Don, Russia
}

The article explores the issues of innovation in the area of agriculture of the Russian Federation. The specifics of the industry and the importance of innovations in this area for the state and the involved enterprises are determined. In addition to studying theoretical aspects, special attention is paid to the analysis of the recent statistics related to the current state of this industry: on enterprises introducing innovations, the volume of innovative products, the amount of innovation costs of organizations, etc. The key difficulties and trends in the area of innovation in the agroindustrial complex of the country are also identified. As a result of this study, a conclusion is formulated concerning the effectiveness of the implementation of the innovative component in the production, organizational and other areas of enterprise activities along with some recommendations developed to strengthen the innovative development of enterprises in the sector in question.

Keywords: innovation; innovative activity; innovation potential; agriculture; agroindustrial complex

\section{Introduction}

In today's conditions, the role of innovations and innovative activity of enterprises across various sectors of the economy is becoming more and more important, since they lead to formation of key competitive advantages by companies and organizations. In addition, they are important elements in increasing the efficiency of various industries and maintaining good positions both within and outside the country (Podkolzina \&Pavlyuk, 2018).

That is why the purpose of this study is to determine the key trends and to analyze the current state and identify key problems with innovations in relation to Russian agricultural enterprises.

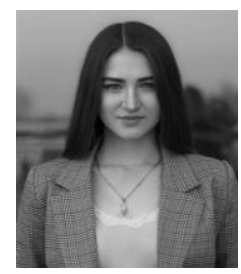

Galina Smolnikova

Graduate student, South Russia Institute of Management, Russia Presidential Academy of National Economics and Public Administration (URIU RANEPA), Rostov-on-Don, Russia

Research interests: economic analysis; economics of innovation; agricultural economy.

E-mail:smol-g777@yandex.ru 


\section{Innovation in agriculture}

Agriculture has historically been one of the main sectors of our country's economy. Moreover, this is the sector responsible for the products that are most significant for the life of population. In 2020, the agroindustrial complex took up $4.2 \%$ of the country's GDP. The degree of economic and food security of the state also depends on how well and effectively agricultural enterprises are operating (Bogachev, 2019).

The most economically developed states in the world have already proven that widespread innovations in the agricultural sector have a direct impact on how easily and effectively farmers can enter the global markets, securing high-quality competitive advantages over other enterprises.

It is worth noting that the agroindustrial complex of the most developed agricultural powers of the world belongs to the sixth technological framework, which directly depends on the qualitative introduction of innovations at various stages of organizations' activities. These include the use of alternative energy sources, nanotechnologies, automation of various production processes, etc. (Dedeeva \& Lapaeva, 2016). However, most of agricultural enterprises in Russia are lagging behind in this rather high level and are more likely to belong to the third or fourth technological frameworks, thus not meeting the requirements of today's markets (Oborin, 2018).

To date, Russia has many different state programs of both federal and regional levels that have been operating for many years, however, the issue of innovations at agricultural enterprises still remains quite a complex one: the existing innovative potential is underused, extensive development tools are mostly used, organizational and marketing structure of production has not been seriously improving for years, etc. (Kaparova, 2019). As a result, the agroindustrial complex of our country, to some extent, does not correspond to the development level of the similar enterprises from the most economically developed states in terms of productivity, which is mostly due to insufficiently developed technical and technological components of the production processes, lack of cooperation with the local scientific community, etc. Because of this, our enterprises do not have sufficient competitiveness at the world markets, and this fact puts them at a disadvantageous position (Pastukova, 2019).

In agriculture, enterprise innovation may refer to many elements and actions, the purpose of which is to form fundamentally new or improved products and production methods that correspond to the current level of development in terms of scientific and technological progress. In its turn, innovative activity should be understood as a certain indicator of the intensity with which innovations in this area are formed, introduced into practical activities and then applied further in various directions (Nutakhina \& Apikova, 2017).

\section{Specificity of the innovations introduction within the agroindustrial complex}

The agricultural sector has a range of its own, highly specific features in terms of economic activity, which are associated with both the production process itself and with many external factors that directly impact on the possibility of applying any innovations in the activities of enterprises (Nikonova, 2017). Among the key specific features of this sphere/sector are the following: 


\section{INNOVATION IN RUSSIAN AGRICULTURE:}

- a wide range of agricultural products as such;

- close interaction of production technologies with natural processes involving plants and animals;

- strong dependence of certain sectors of agriculture upon specific conditions due to geographical location, climate and weather conditions (Nikonova, Trofimov, 2018);

- high dependence of agricultural production on seasonality;

- low degree of cooperation between agricultural organizations and enterprises belonging to knowledge-intensive industries, primarily due to different areas of interest (Bogachev \& Polyakova, 2020);

- weak innovative activity in the field of agribusiness related to the need of society in the most profitable products of this sector, which does not allow enterprises of this industry to raise prices in order to accumulate funds for the subsequent introduction of innovations;

- strong influence of government support when it comes to innovations in the activities of agricultural organizations;

- low level of qualifications at agricultural enterprises in relation to innovation or even complete lack of the appropriate skills;

- long duration of the processes related to creation and introduction of innovations, which is also related to the specificity of using living organisms in the activities of agricultural enterprises;

- weak interaction of the agroindustrial complex with the scientific sector;

- the focus of innovation is more on the modernization of the already existing products and processes rather than development of fundamentally new ones (Bugara, 2016).

Also, the processes of introducing and developing innovations at agricultural organizations strongly depend on many limiting factors peculiar for the country's economy overall. These include the current uncertainty of the economic situation in general, high level of competition among producers, rising inflation, reducing demand for some categories of products (as well as changing structure of demand), lack of investment "injections" in the enterprises of the agroindustrial complex, orientation towards import substitutes, etc. (Hamidov et al., 2019).

\section{Analysis of innovative activity of Russian agricultural enterprises in today's conditions}

It can be stated here that various enterprises in Russia's agriculture are somehow using some of the innovations, still, the overall level of innovative activity in this sector is relatively low, which indicates to the insufficient use of the innovative potential of the sector in today's conditions (Tab. 1). 
Table 1 - Level of innovative activity of Russian agricultural enterprises, in \% (Source: Rosstat, 2021)

\begin{tabular}{|l|c|c|c|c|}
\hline & \multicolumn{2}{|c|}{2017} & \multirow{2}{*}{2018} & \multirow{2}{*}{2019} \\
\cline { 2 - 3 } & $\begin{array}{c}\text { by criteria 3rd } \\
\text { edition Oslo } \\
\text { Manual }\end{array}$ & $\begin{array}{c}\text { by criteria 4th } \\
\text { edition Oslo } \\
\text { Manual }\end{array}$ & 2018 & 9,1 \\
\hline Total & 8,5 & 14,6 & 12,8 & \\
\hline $\begin{array}{l}\text { of them: } \\
\text { growing annual crops }\end{array}$ & 4,2 & 5,1 & 4,0 & 4,8 \\
\hline growing perennial crops & 3,3 & 4,6 & 1,4 & 2,4 \\
\hline growing seedlings & 2,1 & 6,3 & 5,6 & 5,0 \\
\hline livestock production & 3,9 & 4,8 & 4,2 & 4,0 \\
\hline mixed agriculture & 1,3 & 1,3 & 9,4 & 2,8 \\
\hline $\begin{array}{l}\text { supporting activities in the } \\
\text { field of crop production and } \\
\text { post-harvest processing of } \\
\text { agricultural products }\end{array}$ & 2,4 & & & \\
\hline
\end{tabular}

Based on the data in Tab. 1, it can be concluded that the level of innovative activity of enterprises of the Russian agroindustrial complex is quite unstable and tends to decrease in certain areas.

Thus, the level of innovative activity of enterprises engaged in the cultivation of perennial crops during the period from 2017 to 2019 decreased to $2.4 \%$, in other areas the growth of this indicator is observed, however, it is not stable (growing in some years and then falling in others).

Table 2 - Share of Russian agricultural enterprises implementing technological innovations, in \%

(Source: Rosstat, 2021)

\begin{tabular}{|l|c|c|c|c|}
\hline & \multicolumn{2}{|c|}{2017} & \multirow{2}{*}{2019} \\
\cline { 2 - 4 } & $\begin{array}{c}\text { fy criteria 3rd } \\
\text { edition Oslo } \\
\text { Manual }\end{array}$ & $\begin{array}{c}\text { by criteria 4th } \\
\text { edition Oslo } \\
\text { Manual }\end{array}$ & 2018 & 2019 \\
\hline Total & 7,5 & 20,8 & 19,8 & 21,6 \\
\hline $\begin{array}{l}\text { of them: } \\
\text { growing annual crops }\end{array}$ & 3,9 & 6,2 & 5,2 & 7,5 \\
\hline growing perennial crops & 2,6 & 6,9 & 2,2 & 4,7 \\
\hline growing seedlings & 2,1 & 20,0 & 14,3 & 12,5 \\
\hline livestock production & 2,9 & 4,4 & 4,7 & 5,3 \\
\hline mixed agriculture & - & - & 16,3 & 8,9 \\
\hline $\begin{array}{l}\text { supporting activities in the field of } \\
\text { crop production and post-harvest } \\
\text { processing of agricultural products }\end{array}$ & 2,1 & 4,6 & 6,3 & 7,4 \\
\hline
\end{tabular}




\section{INNOVATION IN RUSSIAN AGRICULTURE:}

Thus, within the agricultural sector as a whole, there is an increase in the share of enterprises introducing innovations in the period 2017-2019, which is a positive sign. The most significant growth is observed in the areas of annual crops cultivation, animal husbandry and agricultural support.

Table 3 - Volume of innovative products in Russia's agricultural production, bln rubles (Source: Rosstat, 2021)

\begin{tabular}{|c|c|c|c|c|c|c|}
\hline & \multicolumn{6}{|c|}{ In-house goods shipped, works and services performed in-house } \\
\hline & \multicolumn{3}{|c|}{ total } & \multicolumn{3}{|c|}{$\begin{array}{l}\text { including innovative goods, } \\
\text { works, services }\end{array}$} \\
\hline & 2017 & 2018 & 2019 & 2017 & 2018 & 2019 \\
\hline Total & 57611 & 68982 & 92253 & 4166 & 4516 & 4863 \\
\hline $\begin{array}{l}\text { of them: } \\
\text { growing annual crops }\end{array}$ & 549 & 0,68 & 1711 & 10 & 10 & 26 \\
\hline growing perennial crops & 14,4 & 20,18 & 40920,4 & 442,5 & 491,5 & 0,846 \\
\hline growing seedlings & 2,1 & 4,2 & 3,5 & 0,45 & 0,48 & 0,09 \\
\hline livestock production & 963,2 & 1033 & 1255 & 16,6 & 21,7 & 40,9 \\
\hline mixed agriculture & 6,3 & 14,8 & 16,44 & - & 0,2 & 1,04 \\
\hline $\begin{array}{l}\text { supporting activities in the } \\
\text { field of crop production } \\
\text { and post-harvest } \\
\text { processing of agricultural } \\
\text { products }\end{array}$ & 17,2 & 18,8 & 54,5 & 0,31 & 0,65 & 0,28 \\
\hline
\end{tabular}

Table 4 - Share of innovative products of agricultural enterprises in the total production volume in Russia, in \%

(Source: Rosstat, 2021)

\begin{tabular}{|l|c|c|c|}
\hline & 2017 & 2018 & 2019 \\
\hline Total & 7,2 & 6,5 & 5,3 \\
\hline $\begin{array}{l}\text { of them: } \\
\text { growing annual crops }\end{array}$ & 1,9 & 1,5 & 1,5 \\
\hline growing perennial crops & 3,1 & 2,4 & 2,1 \\
\hline growing seedlings & 21,4 & 11,4 & 2,5 \\
\hline livestock production & 1,7 & 2,1 & 3,3 \\
\hline mixed agriculture & - & 1,4 & 6,4 \\
\hline $\begin{array}{l}\text { supporting activities in the field of crop } \\
\text { production and post-harvest processing of } \\
\text { agricultural products }\end{array}$ & 1,8 & & \\
\hline
\end{tabular}


In the period from 2017 to 2019, the volume of innovative products in the agroindustrial complex tended to increase, which is directly correlated with the overall increase in the volume of products produced in the country. The most active growth of the indicator was observed for the enterprises engaged in the cultivation of annual and perennial crops, animal husbandry, and mixed agriculture. Enterprises operating in the fields of seedling cultivation and auxiliary areas of agricultural production, on the contrary, have reduced their volumes of innovative products, which indicate the presence of certain problems in this area.

From Tab. 4, the share of innovative products of the agroindustrial enterprises in the period from 2017 to 2019 tended to decrease. The sharpest decline was observed for the companies engaged in seedling cultivation, where the figure fell from $21.4 \%$ to $2.5 \%$. Growth was observed only for mixed agriculture.

Table 5 - Expenses of Russian agricultural enterprises on innovative activities, bln rubles

(Source: Rosstat, 2021)

\begin{tabular}{|l|c|c|c|}
\hline & 2017 & 2018 & 2019 \\
\hline Total & 1404 & 1472 & 1954 \\
\hline $\begin{array}{l}\text { of them: } \\
\text { growing annual crops }\end{array}$ & 8,3 & 13,3 & 38,9 \\
\hline growing perennial crops & 0,1 & 46,2 & 62,4 \\
\hline growing seedlings & 0,012 & 219,1 & 11,6 \\
\hline livestock production & 6403 & 6454,1 & 10002,9 \\
\hline mixed agriculture & - & 0,73 & 0.065 \\
\hline $\begin{array}{l}\text { supporting activities in the field of crop } \\
\text { production and post-harvest processing } \\
\text { of agricultural products }\end{array}$ & 1,02 & & \\
\hline
\end{tabular}

According to Tab. 5, the costs of enterprises assigned for the development, implementation and implementation of innovations in the period from 2017 to 2019 increased in such areas as growing annual crops and livestock. As for the cultivation of perennial crops, seedlings, mixed agriculture and auxiliary industries, the costs of organizations have decreased.

This is a fairly important indicator, since, for example, relative to the industry overall, they are 2 times lower. In today's conditions, this situation is rather damaging since insufficient investments in the innovative potential of agricultural enterprises lead to low quality or frequency of improvement in part of fixed assets, not discovering new directions for activities, and in the longer term - this directly and negatively affects the formation of competitive advantages of agricultural products at various markets.

In addition, about $50 \%$ of all expenditures on innovative activities of Russian agricultural enterprises are aimed exclusively at purchasing new equipment, which indicates the predominance of the extensive mode in agriculture's development.

At the same time, the costs spent on introducing nano- and/or biotechnologies, alternative energy sources, engineering, etc. are quite low. This is primarily due to low 


\section{INNOVATION IN RUSSIAN AGRICULTURE:}

awareness and insufficient competences among the leadership of agricultural enterprises and also due to the lack of understanding of the importance of innovations for today's production (Mochalova \& Korsakova, 2018).

Own R\&D in the field of innovation accounted for about $25 \%$ of the total cost of innovation of the agricultural enterprises in Russia. This indicates that many organizations of the sector do not pay sufficient attention to the scientific and technological component in their production. This is the case due to a high degree of isolation of the subjects of innovative processes, and also lack of stable and rational mechanisms that could have been used (Ditkovsky, 2017).

\section{Challenges and complexities of agricultural innovations}

Thus, a number of problems existing in the field of agricultural production and hindering the introduction and development of innovations at Russian agricultural enterprises can be outlined:

- lack of a fully fledged and specific enough agricultural innovation program with all the necessary tools to sustain it;

- weak technical and technological basis for improving significant imbalances in the agroindustrial complex;

- predominance of extensive development methods in agricultural production, that is, production at various agricultural enterprises increases due to expansion in their fixed assets, rather than due to the introduction of innovations;

- the use of innovations is rather standalone and is mostly focused on improving the technical support of agricultural enterprises rather than technological one;

- low level of innovative marketing in agriculture overall;

- preferential application of more expensive foreign innovations, despite the fact that Russian developments are sometimes better and, at the same time, more profitable. Because of this, some enterprises are forced to dedicate higher costs for certain innovations which do not stimulate but rather prevent the use of new developments in their activities more often and more efficiently (Shilova, 2017);

- the absence of dedicated departments at most of Russian agricultural enterprises that would have been engaged in the development, search and implementation of the needed innovations in the production processes;

- low level of agricultural innovation in the country in general;

- lack of awareness concerning most relevant innovations among the management of enterprises and or employees responsible for innovative and other related activities (Perepelkin et al., 2019);

- frequent discrepancy between the specific requests of certain agroindustrial enterprises and the innovations actually existing;

- lack of private investment in the innovation activities which is exacerbated by low level of public funding;

- high costs and other difficulties with obtaining loans for the implementation of innovative projects in agriculture;

- there is a significant gap between the capabilities of large and small farmers, which is why innovations are mainly applied by the largest industries, while mid-sized and small enterprises are still operating in the most traditional ways (Savvin, 2019). 


\section{Results and recommendations}

Thus, it can be concluded that one of the key goals for the agriculture of our country today is formation of all necessary conditions and prerequisites for improving the processes of innovations' development and implementation at the enterprises of the agrarian sector. Maximum efficiency in the innovations of the agroindustrial complex of the country can be achieved only with the joint activity of the state in the legislative and economic spheres, the scientific community, which is engaged in the creation of various new technologies, in the field of education in the direction of training specialists for the agricultural sector and private investors, which should ensure the implementation of the innovative potential of enterprises financially (Reznichenko \&Andreev, 2018).

In order for the maximum number of Russian agricultural enterprises to innovate at various stages of their organizational activities, it would be necessary to improve many elements from various areas at the same time:

- development of an appropriate legislative framework;

- creation and maintenance of conditions for technical and technological improvement of the organizations' activities;

- developing effective tools to stimulate and sustain enterprise-level innovations;

- building necessary infrastructure for agricultural innovations (Kornilova et al., 2018);

- information support for innovative processes overall;

- high-quality and sufficient training for those specialists whose activities include development, implementation and application of innovations in agriculture;

- creation of a stable communication mechanism for the agroindustrial complex and the related sciences (Otinova, 2019).

Qualitative growth of innovative activity of Russian agricultural enterprises will have a positive impact on the aggregate economic growth of the country, and will also provide competitive advantages to domestic producers entering the international markets, thus also accelerating the rural development processes, improving the quality of agricultural products, etc.

\section{References}

Bogachev, A. I. \& Polyakova, A. A. (2020). Innovative potential and innovative activity of Russian enterprises. Polythematic network electronic scientific journal of Kuban State Agrarian University, 64:156-165.

Bogachev, A.I. (2019). Innovation in Agriculture of Russia: Modern Trends and Challenges. Bulletin of NGIEI, 5 (96).

Bugara, A.N. (2016). Innovation in agriculture. Agri-food economy, 9:17-22.

Dedeeva, S.A. \& Lapaeva, O.F. (2016). Innovations as the main factor in the development of agriculture in the region in the conditions of import substitution. Bulletin of Orenburg State University, 8 (183):29-33.

Ditkovsky, K.A. (2017). Innovative activities of agricultural organizations.HSE. 


\section{INNOVATION IN RUSSIAN AGRICULTURE:}

Hamidov, G.S., Tepsaev, A.N. \&Hajimuratova, D.Z. (2019). Innovation and competitiveness are the main factors for the sustainable development of industrial enterprises. Innovations, 1:14-19.

Kaparova, M.A. (2019). The main directions of innovative development of agriculture in the region.Dissertation for the degree of Candidate Econ. sciences. Novosibirsk.

Kornilova, L.M., Ivanov, E.A. \& Ivanov P.A. (2018). Stimulating the innovative activity of agricultural organizations - the basis for digitalization of the agro-industrial complex. Innovative development of the economy, 5 (47):52-58.

Mochalova, Y.V. \& Korsakova, I.V. (2018). The process of innovating the Russian agro-industrial complex: trends, opportunities, restrictions. Bulletin of the Volga State University. 4 (37):140146.

Nikonova,G.N. \& Trofimov, A.G. (2018). Innovative activity of agricultural organizations as a reflection of the content of their competitive strategies. Nikon readings, 13:166-168.

Nikonova, Y.I. (2017). Assessment of the impact of innovations and their financing on the economic growth of the national economy. International Research Journal, 11 (53): 53-59.

Nutakhina, Y.G. \& Apikova, M.B. (2017). Innovative development of agroindustrial complex in modern conditions. Innovative activity in the modernization of agro-industrial complex: Materials of the International Scientific and Practical Conference of students, graduate students and young scientists. Publishing House of the Kursk State Agricultural Academy.

Oborin, M.S. (2018). The main directions of agricultural modernization in modern Russia. Bulletin of Mari State University, 2 (14).

Otinova, M.E. (2019). Organizational and economic mechanism of innovative development of large business in the agro-industrial complex. Collection of scientific works of GNU NIIEAPK CCR of Russia. Voronezh.

Patsukova, I.G. (2019). Innovation in the agro-industrial complex. Problems of Contemporary Economics, 17:135-139.

Perepelkin, I.G., Shatokhin, M.V. \& Motina, O.A. (2019). Assessment of the production potential and competitiveness of industrial and agricultural enterprises. Bulletin of the Kursk State Agricultural Academy, 4:23-26.

Podkolzina, I.M. \& Pavlyuk, A.V. (2018). Ensuring sustainable development of the agricultural economy within the framework of an innovative approach. Problems of Economics and Legal Practice, 1:23-27.

Reznichenko, S.S. \& Andreev, S.Y. (2018). Development of the agricultural sector of the economy based on innovation. Young Scientist, 8: 27-28.

Rosstat (n.d.). Science and innovation. Available online at:https://rosstat.gov.ru/folder/14477.

Savvin, A.V. (2019). Ways and Problems of Innovative Renewal of the Agricultural Sector of the Economy. Organizational and Economic Mechanism of Innovative Development of the AgroIndustrial Complex: Collection of scientific works of the GNU NIIEAPK CCR of Russia. Voronezh. 
Shilova, N.V. (2017). Problems of developing innovations in the agro-industrial complex and ways to solve them. Aeconomics: economics and agriculture, 2 (6):1-5.

Paper submitted

Paper accepted for publishing

Paper published online
11June2021

17 August 2021

30 September 2021 